\title{
Effective Complementary Policies to "Aid for Trade" to Enhance Pro-Poor development strategy in Africa
}

\author{
Ahmed M. Ezzat \\ Collage of International Transport \& Logistics, Arab Academy for \\ Science, Technology and Maritime Transport - Cairo - Egypt
}

\begin{abstract}
Poverty reduction is one of the main reasons taken into consideration within successive governments all over the world. Economic development and poverty reduction need consistent policies between recipient, donor countries and other international actors. Accordingly, the WTO started focusing on trade-related technical assistance for the leastdeveloped countries (LDCs). Even though WTO is not a development agency, it tries to ensure that trade openness policies work together with development assistance mechanisms effectively as a requirement. This led to launching various technical assistance and capacity building programs on both bilateral and multilateral levels. Aid for Trade (AfT) agenda is considered one of these programs that enable developing countries to benefit from trade liberalization. In many cases, these programs fail in reducing poverty in recipient countries. This paper tests the hypothesis that AfT programs help remove poverty in African countries as well as determines the efficient components of complementary policies. This hypothesis is tested using annual data for 48 countries within 1996-2014. The results of this paper confirms the previous studies that trade openness harms the poor and that AfT was insignificant in reducing poverty. This paper suggests that the coordination between donors and recipients is required. Additionally, AfT programs in African countries need to be supported with some activities that would help them benefit from the integration in world trade.
\end{abstract}


Key Words: African countries, Aid for trade, Multidimensional poverty index, Poverty in Africa, System GMM estimator for dynamic panel data models.

\section{Introduction}

Despite the high growth rates in several developing countries, the poverty gap continues to increase dramatically in most of them. This makes poverty reduction to be among the top priorities in development plans, not only within developing countries, but also it becomes a key commitment of donor agencies.

The WTO believed that even though it isn't responsible for giving development assistance, it has to coordinate with the rest of international agencies by managing the world economic system. The idea of marginalisation of world trade of LDCs, mainly in Africa, played a critical role in engaging the WTO in generating the trade-related technical assistance in 1997 WTO Ministerial Conference in Singapore. Accordingly, the WTO launched the Aid for Trade (AfT) initiative to help LDCs and developing countries. However, in many cases, this initiative did not achieve its goals because of small sized subsidies, limited funding, lack of compatibility with the development plans of recipient countries, non-sustainability and associated conditions, or the inability of LDCs and developing countries to absorb these programs (Basnett et al., 2012; Hayashikawa, 2009).

This leads to the belief that trade openness alone is insufficient in enhancing economic development and poverty reduction. Consequently, the need for studying the relationship between trade, development and poverty reduction increased dramatically. The WTO's Doha Development Round witnessed a focus on the development deficit that can result from the 
multilateral trade liberalization. Therefore, in 2005 Hong Kong declaration, the WTO Director-General started consultations with international organizations that insures providing convenient mechanisms to include further financial resources to aid for trade in a trial to help make trade contribute to development goals. Accordingly, aid for trade is reassessed in order to strengthen its coordination with other areas of economic policy (Hayashikawa, 2009; OECD, 2006).

The World Trade Organization (WTO) and the Organization for Economic Co-operation and Development (OECD) started reviewing the performance of AfT every two years since 2005 . A published report in 2007, notified that aids and investment were increasing. In 2009, a report was created that stressed the need to diversify the methods used by donors and recipients to address AfT. In 2015 report, they stated that despite the achievements since 2005, a number of challenges still exist. One of the main challenges is the coordination needed between AfT initiative and Sustainable Development Goals including the impact of trade on the poor (OECD and WTO, different issues).

Furthermore, it can be concluded that the positive impact of AfT in reducing poverty is still doubtful due to the lack of coordination between AfT and policies adopted by the rest of the international agencies.

The purpose of this paper is to test the effectiveness of AfT's enhancement in reducing poverty in Africa and overcoming the challenges that hinder the impact of AfT to be effective in poverty reduction. The research also suggests some practices for both donors and recipients to overcome these challenges. The rest of the paper is organized as follows. The second section discusses a relevant literature. The third section clarifies the 
methodology and the specification of the model. The fourth section studies the characterization of data used in the model. The fifth section introduces some empirical results. The last section includes a discussion of the results and policy implications.

\section{Literature Review}

The relationship between foreign aid and poverty reduction, especially in developing countries and LDC's, has been given a great attention by economists. This relationship leads to a great source of debate in the literature. While some confirmed that AfT is quite important in enhancing development then in reducing poverty, others stated that it is better to depend on bootstraps. This section studies the relevant literature of poverty and appropriate programs, AfT principles and the best practices of AfT to be effective in reducing poverty.

According to Addae-Korankye (2014) and Bradshaw (2005), the five main categories, according to the root causes of poverty, are individual deficiencies; cultural belief systems; economic, political, and social distortions; geographical disparities and cumulative and circumstantial interdependencies.

The first set relates poverty to the lack of individual abilities and motivations of the poor (Addae-Korankye, 2014; Egye and Muhammad, 2015; McCaston and Rewald, 2005) and argue that they can remedy poverty efficiently using social and welfare anti-poverty programs (Bradshaw, 2005).

The second category links poverty to beliefs, traditions and values which generates the culture of poverty (Addae-Korankye, 2014) and sets anti poverty programs that includes changing the distortions in the existing culture and working on youth ${ }^{1}$ (Bradshaw, 2005; Jordan, 2004).

${ }^{1}$ Focusing on educational programs is required according to this set of theories. 
The third group connects poverty to economic, political, and social systems that limit the capabilities of individuals (AddaeKorankye, 2014; Jordan, 2004; McCaston and Rewald, 2005). Here changing the system through working on grassroots, institutional and national levels are needed (Bradshaw, 2005).

The fourth class relates poverty to circumstances concentrated in a specific geographical area. In order to recover, efforts should focus on improving local industry competitiveness and enhancing both infrastructure and private investment in poor areas (Bradshaw, 2005; Egye and Muhammad, 2015).

The last category demonstrates the link between poverty and economic distortions as a two way causality creating a cumulative set of problems to break the cycle of poverty ${ }^{2}$ (Bradshaw, 2005; Egye and Muhammad, 2015; Jordan, 2004). Reducing poverty here requires concerted efforts to break poverty cycles through enhancing supply-side capabilities in poor developing countries (Bradshaw, 2005).

Regardless of the theoretical explanations for poverty, all theories - even those which stated explicitly that the poor are responsible for their own problems, declare that reducing poverty and develop communities should not be the responsibility of only the poor people ( Bradshaw, 2005; Stark, 2009). In this context, AfT initiative started during the sixth World Trade Organization Ministerial meeting ${ }^{3}$ as a trial to help developing countries overcome supply-side constraints (ICTSD,

\footnotetext{
${ }^{2}$ One of the sources of poverty cycles is the nature of specialization of developing countries after the new international division of labor which is reflected on the distribution of benefits of the integration in the world trade between poor developing countries and developed countries.

${ }^{3}$ The sixth World Trade Organization Ministerial meeting held in Hong Kong (China) in 2005 targets expanding exports and enhancing domestic productive capacities
} 
2012; OECD, 2006; OECD, 2011; OECD/WTO, 2013; Turner et al., 2008; UNCTAD, 2012).

Agboghoroma et al. (2009) stated that the basis of AfT is related to economic development and how it can be affected by trade. While studying the theoretical background of the relation between trade and growth, a source of debate can arise between international and domestic approaches of development. According to the international approach of development, liberalizing trade can help enhance competition, attract foreign investment and technology, and improve the efficiency of using resources. Additionally, the complementary policies to trade liberalization help in enhancing both economic and social development including reforms in institutional, educational, legislative, labor and technological frameworks.

In order to help developing countries in maximizing the benefits of the integration in the world trade, the WTO Task Force set a combined package of activities included in the AfT initiative. These activities include (Agboghoroma et al., 2009; OECD, 2006; OECD/WTO, 2013):

1. Technical trade-related assistance which consists of all the activities related to developing trade strategies, negotiating trade agreements and facilitating their implementation.

2. Trade-related infrastructure which involves all the types of support related to investing in physical infrastructure to connect the domestic market with the international markets including transport, storage, communications and energy as a mean to reduce high costs that impede trade.

3. Productive capacity building which includes all the types of support targets diversifying production structures and push the investments towards sectors depending on the comparative advantage. 
4. Trade-related adjustment assistance which includes all the complementary actions related to helping developing countries to gain from trade liberalization such as tariff reduction, improving port operations, adjusting exchange rate policies, removing policy barriers to entry and other actions targeting improving the terms of trade.

5. Trade development which involves all the actions related to attract investment towards financing trade sectors and market analysis.

6. Other trade-related needs which include actions of particular importance to attract new investment related to securing property rights, maintaining high-quality working conditions, enhancing macroeconomic stability, increasing public investments in education and other public goods and harmonizing with the trade development plans in partner countries.

By studying the relationship between trade liberalization from one side and development and poverty reduction from the other, another source of debate in the literature can be found. While some highlight the causality between them, others proved that trade liberalization has led to the increase in underdevelopment and poverty in a number of countries. OECD (2011) mentions that even though all the countries have had remarkable reduction in income poverty made use of international trade, empirical studies do not agree with the causality between AfT and poverty reduction neither directly nor through affecting growth. Turner et al. (2008) confirms this idea saying that even though trade liberalization supported in enhancing growth and poverty reduction in several countries like Hong Kong, Singapore, South Korea and Mauritius in a variety of ways, however other countries succeed in reducing poverty without substantial increases in trade. 
ICTSD (2012) and OECD/WTO (2013) clarifies that it is very difficult to assess the effect of AfT on rising income and poverty reduction for both methodological and practical reasons ${ }^{4}$. Turner et al. (2008) confirms the difficulty of having systematic empirical investigations as the relationship between trade liberalization on poverty is extremely complex and case sensitive. Additionally, the relationship depends on numerous factors including the heterogeneous characteristics of poor people, the differences of trade liberalization policies adopted, whether the country is endowed with abundant mineral wealth, the quality of the existing infrastructure and the existence of complementary policies consistent with the reforms in trade.

IMF (2007) illustrates that the theoretical relation between trade liberalization and poverty reduction can be generated from the Stolper-Samuelson theorem. It implies that in a two country with two factors model, developing countries with abundant low skilled labors can gain from reducing tariffs on imports as trade liberalization results on an increase in the wage rate for low skilled labor and a decrease in wages for high skilled labor. This can lead to a reduction in income inequality within developing countries. In the cross-country analysis, the study found that even though trade liberalization led to poverty reduction in Mexico, China and India, however income inequality increases. The study explains the increase in the inequality gap by the relatively higher reduction of tariffs on less-skilled labor intensive sectors during the reform. In spite of the increase in the inequality gap, the study argues that low-skilled labor have benefited in absolute terms as a result of improving working conditions after the policy reforms.

${ }^{4}$ These reasons include the diversity of trade objectives, tools, activities, sectors and firms objectives. 
Basnett et al. (2012) and OECD (2011) state that even though AfT and trade liberalization lead to poverty reduction in the long run and on average ${ }^{5}$, however this effect depends on several factors such as the structure of the economy; whether tradeinduced growth occurs in sectors which employs a large number of the poor; how much growth translates into job creation and wage increases; whether excess labor can be absorbed; the extent to which the poor are equipped to take advantage of new job opportunities and the harmony between AfT activities and the complementary policy choices.

Accordingly, a comprehensive assessment which uses multiple measurements is needed to be used. Additionally, they organized the literature studying the effects of AfT into three categories: aggregate cross-country approaches, sectoral reviews, and project level evaluations. For the purpose of evaluating the effectiveness of AfT in poverty reduction, this paper uses the first approach.

Pinstrup-Andersen (1998) states that past effective development assistance helped emerging countries in Asia and Latin America to enhance economic growth and reduce poverty. Additionally, the study stressed that the more the focus on the reduction of rural poverty, the higher the benefits of the aids because most of the poor are found in rural areas.

Anyanwu and Erhijakpor (2010) estimated the effects of international remittances on poverty in 33 African countries over the periods 1990-2005. They found that international remittances reduce the level, depth, and severity of poverty in Africa.

\footnotetext{
${ }^{5}$ Basnett et al. (2012) set several channels for the causality between AfT and poverty reduction including the effects of AfT and trade liberalization on lowering prices, increasing competition and gaining from the economies of scale.
} 
Versailles (2012) studied the budgeting and planning processes in Rwanda and how they lead to enhancing the economy. He stated that the coordination between planning, budgeting and aid results in Rwanda becoming an example in achieving rapid growth and poverty reduction.

OECD and WTO (2013) present the causality between AfT and poverty reduction through introducing three mechanisms. The first is the role of AfT in enhancing the growth of exports and imports. The second is the transformation of the growth of trade that lead to an increase in both productivity and income growth. The third is the effect of the growth of income on poverty reduction.

Melo and Wagner (2015) introduced several channels in which AfT can enhance in reducing poverty. These channels include improving infrastructure and productive capacity. Improving infrastructure can result in reducing poverty by affecting labor income through changing wages and production through changing prices or access to infrastructure and consumption bundles after changes in prices of consumption goods. Improving productive capacity affects poverty through improving agricultural production and diversifying production capabilities. OECD and WTO (2011) added to the role of AfT in enhancing trade in sectors with intensive employment opportunities for women to support gender equality because according to the study "women are more vulnerable to chronic poverty".

On the other hand, several studies found that trade liberalization increases income inequality and accordingly supported the bootstraps view in reducing poverty. Nicita et al. (2011) uses household surveys for six Sub-Saharan African countries (Burkina Faso, Cameroon, Côte d'Ivoire, Ethiopia, Gambia, Madagascar) to study the effects of liberalizing trade 
on the distribution of income. They found that the poor are better off with protection, especially for agriculture goods, in all countries except Ethiopia, and that trade liberalization benefits the rich more in these countries.

Winters and Martuscelli (2014) confirms the same finding in both the short and medium terms that trade liberalization reduces the protection of agricultural products which affects the poor directly. ICTSD (2012) proves during his study of the effectiveness of AfT to enhance trade performance in four countries (Cambodia, Malawi, Mauritius, and Nepal) that although AfT led to improving trade performance in the majority of countries in his study, poverty reduction was a challenge in AfT programs.

OECD and WTO (2013) stated that the causality between AfT and poverty reduction is not necessarily held in every country at a given time. Many factors affect the relationship between trade growth and income growth including indebtedness, governance, the existence of complementary policies in finance, education, and/or investment. Similarly, in the last link of the chain, from growth to poverty reduction, the basic structure of the economy - initial distribution of income, land or natural resource ownership, the skill of the labor force, or the labor-intensity of production - strongly affects the pace of poverty reduction and the distribution of the benefits from the income growth.

Turner et al. (2008) declares that although trade liberalization can help reduce poverty through increasing average income, it will create losers as it will push groups of people into poverty. Additionally, trade liberalization and increasing trade flows have negative effects including the pollution generated from the intensive production which has negative impacts in the long run. Amiti and Davis (2012) confirmed the idea of having losers in their study that was led by the effects of trade liberalization on wages. They found that although tariff reduction will boost 
wages in exporting firms and those depending more on imported inputs, it will reduce wages in import competing industries and those who depend more on domestic inputs.

Gourdon et al. (2008) stress the same idea saying that trade liberalization is associated with increases in income inequality if the country has highly endowment skilled workers and capital while having workers that have very low education levels. This strongly supports the factor-proportions theory because workers with low education levels are low skilled workers and are expected to be confined to non-traded activities. The inequality of income will increase as a result of trade liberalization if the poor consume the exported goods intensively.

In a study of reassessing the gains from trade liberalization for sub-Saharan Africa, Fosu and Mold (2008) confirmed the same idea by supporting their findings and stating that African countries cannot expect substantial benefits from further multilateral liberalization. Additionally, the study suggests that the ultimate impact on poverty reduction is likely to be small or even negative.

As a result of the confused conclusions of the literature which studied the relationship between AfT and poverty reduction, studies focused their attention on the main challenges and the factors that can lead to enhancing the positive effects of trade liberalization on the economic performance of the recipient countries.

Several studies analyze the main challenges facing the ability of LDCs and developing countries to attract AfT and its effects on poverty reduction. OECD (2006) mentioned three main challenges. The first is the ability of the government to enhance the absorptive capacity of the economy and maintain a stable macroeconomic framework that can target the efficient use of aid to deliver services and select projects in a way that can 
reduce poverty and compensate the negative impact of trade liberalization on the inequality gap. The second is improving public financial management while facing increasing restrictions on domestic resource mobilization and rationalization of expenditure. The third is the possibility of the real appreciation in the value of the recipient's country currency, as a result of the increase in the flows of aids to the country, which can negatively affect the competitiveness of its products abroad (The "Dutch disease" effect).

Basnett et al. (2012) added another type of challenge which is generated by those groups likely to lose from policy changes after adopting trade liberalization. If they are well organized and influential, they can block reforms and transfer the benefits of liberalization to most of their residents. The study adds that the AfT is relevant to improving the performance in countries suffered from supply side constraints. In this context, if the problems restricting the ability to use trade as a motivator to enhance economic performance are affected more by other factors like the geography of the country or being land-locked, the ability of AfT to influence the economic performance is dubious.

In his study Pinstrup-Andersen (1998) added to the governmental capacity challenges to absorb the increase in AfT and enhance its effects to improve the economic performance through other factors including the population growth especially in rural areas which leads to the migration to urban areas and a population pressures on available services, the food insecurity mainly putting into consideration the income inequality in the developing countries, the huge absolute number of workers in agriculture who are poorer than those working in other activities putting into consideration that the poor who work in agriculture 
are better off with protectionism and the problems of resource scarcities and environmental deterioration.

Hayashikawa (2009) summarized the main challenges into two groups. The first group is caused by donor countries. This group includes some policies adapted that can restrict the effective participation of developing countries and LDCs of the World Trade like restricting the trade liberalization in agriculture and textiles for a long period of time and the liberalization of labor movements across borders. Both harmed the poorest people around the world. The second group resulted from the recipient countries practices including the supply-side challenges including the relatively high costs of doing business, the low level of human capital, poor governance and poor infrastructure.

ICTSD (2012) found different conclusions for each of the following four countries (Cambodia, Malawi, Mauritius, and Nepal). The study interpreted these different conclusions within several factors determining whether the AfT can add value to the recipient country and enhance the economic performance or not. These factors include:

- The balance between the AfT programs and spending on other sectoral programs, mainly health, social programs.

- The AfT programs should focus more on human capacity building and private sector development which are relatively ignored compared to transport, storage, energy, and agriculture sectors in the LDCs studied.

- The balance between the AfT funds and the absorptive capacities of recipient countries.

- The awareness of both public and private sectors about the importance of trade in development goals that lead to the sustainability of AfT programs and confirm their effects.

- The efficient donor coordination which avoid the repetitive of projects. 
OECD (2006) studies the factors that can manage the effectiveness of AfT. The study divided these factors between the recipients and donors. Additionally, the study focused on the Paris Declaration principles on aid effectiveness. From the recipients' point of view the study highlighted the importance of the effective government intervention. In this context the study argued that the market failure results mainly from the government failure as the market mechanism alone fails to achieve the market efficiency. From the study's perspective, the effective government intervention should eliminate corruption and inefficient customs service, enhance institutional capacity and civil society scrutiny, enhance the investment in traderelated administration and infrastructure, and facilitate access to information and enhance transparency. From the donors' side simplification of complex assistance programs, which consume large amounts of administrative resources, is required. Additionally, donors are required to align their development assistance with local development strategies in recipient countries.

Basnett et al. (2012) set the factors affecting determining the type of aid and the effectiveness of AfT programs. In this context the study argued that the effective type of aid is affected by the following factors:

- Recipient's income level: as the flow of aid to infrastructure are more effective for lower-income countries while other aid flows, such as those directed to the business sector, are more effective in higher-income countries.

- The needs and characteristics of the recipient sector of aid: this is critical as the types of aid vary among sectors. 
- The requirements of the geographical regions of recipient countries: there is evidence that the type of aid required varies between geographical regions.

- The binding constraints of the recipient country: not only national constraints to trade need to be studied, but also regional constraints to trade are critical.

- The coordination in the design and implementation of AfT investment programs: in determining the types of aid, the coordination between donors and between donors and recipients is required to constitute AfT priorities and accordingly the types of aid.

3. Methodology, Variable Description and Specification of the Model

This section discusses the model specification to examine the potential contributions of the relevant parts of AfT as prerequisites for poverty reduction. The model is specified using the dynamic panel data techniques based upon the generalized method of moments (GMM) in order to capture the cyclical interdependencies between poverty and its causes. Additionally, pooled ordinary least square (OLS) and panel fixed effect methods are employed as robustness tests. The panel data-set covers 48 African countries ${ }^{6}$ over a period of 19 years (19962014) $)^{7}$.

The countries under this study consist of 28 countries that belong to the group of LDCs and 20 belong to the group of developing countries. Most of them are benefit a little from the

${ }^{6}$ All the African countries except Cabo Verde, Eritrea and Sao Tome and Principe are excluded because of the lack of data.

${ }^{7}$ This period covers 10 years before the start of AfT initiative during the World Trade Organization Ministerial meeting held in December 2005 and 9 years after the start of the initiative. 
international trading system. These countries are shown in the appendix.

For the purpose of this paper, the relevant parts of AfT are identified into three different groups of variables: institutions, infrastructure and human capital in order to capture the main effective components in AfT programs that can help effectively in reducing poverty.

In this context, the dependent variable is derived putting into consideration the multidimensional phenomenon of poverty and the severe lack of data in the group of countries studied. In constructing a multidimensional poverty index (MPI), two dimensions are taken into account (Jordan, 2004) ${ }^{8}$.

1. Deprivation of decent living standards $\left(D_{1}\right)$. In measuring this dimension of poverty, an average of two measurements is used. The first is the proportion of people who suffer from hunger. The second is the percentage of population without access to improved drinking water source.

2. Deprivation of longevity $\left(\mathrm{D}_{2}\right)$. In measuring this dimension of poverty, an average of two measurements is used. The first is the percentage of people with life expectancy less than 65 years. The second is the proportion of children under five mortality rates per 1,000 live births.

Then we used the same methodology that was used in calculating the Human Poverty Index for Developing Countries issued by the United Nations Development Program (UNDP) to generate the MPI by combining these three dimensions into one single measurement giving a greater weight to the most disadvantaged situation. The formula of calculating the MPI is:

${ }^{8}$ The deprivation of knowledge is excluded of the calculation of the MPI because of the lack of data. 


$$
\text { MPI }=\left[\left(D_{1}^{2}+D_{2}^{2}\right) / 2\right]^{1 / 2}
$$

In choosing the independent variables, the same methodology adapted by (Agboghoroma et al., 2009; Arellano and Bond, 1991; Stephen and Mahyudin, 2014) is used. The following independent variables are included:

- InitialGDPpc indicates the level of initial GDP per capita (constant 2010 US\$) for the previous year, i.e. GDP per capita in 1995 is the initial value for the year 1996. (Jordan, 2004).

- WGI describes the aggregate governance indicators calculated as a simple average of 5 dimensions of governance included in the Worldwide Governance Indicators referring to institutional quality. These 5 dimensions are control of corruption, government effectiveness, political stability and absence of violence, regulatory quality and rule of law. The WGI is used as a proxy for the quality of institutions instead of having the 5 variables as the partial correlation coefficient between WGI and the previous 5 dimensions are 0.93, 0.89, $0.73,0.9$ and 0.93 respectively. The values of WGI variable are modified to be a low of 0 to a maximum 5 .

- Unemr refers to unemployment rates as a percentage of total labor force referring to the dependency ratio which increases poverty.

- Healthr describes the total health expenditure ${ }^{9}$ as a percentage of GDP referring to human capital development.

- Eduexp indicates the government expenditure on education as a share of GDP referring to human capital development.

${ }^{9}$ It is calculated as the sum of public and private health expenditure. 
- ISF refers to improved sanitation facilities as a percentage of population with access referring to improvements in physical infrastructure.

- Trade equals exports plus imports of goods and services as a share of GDP is used to study how trade openness can affect poverty.

- ODA refers to net official development assistance, which consists of disbursements of loans and grants by official agencies to promote economic development and welfare.

- Inf indicates the inflation measured as the annual growth rate of the GDP deflator referring to the rate of price change which affects the purchasing power in the economy.

Using these variables and after adding time dummies to express the effect of time on poverty in general and to examine the effectiveness of AfT initiative that started after the World Trade Organization Ministerial meeting held on December 2005, the specification of the model can be shown as follow:

$$
\begin{aligned}
M P I_{i t}= & \alpha_{i}+\beta_{1} M P I_{i(t-1)}+\beta_{2} \text { InitialGDPpc }_{i t}+\beta_{3} W G I_{i t}+\beta_{4} \text { Unemr }_{i t} \\
& +\beta_{5} \text { Health }_{i t}+\beta_{6} \text { Eduexp }_{i t}+\beta_{7} I_{\text {ISF }}+\beta_{8} \text { Trade }_{i t}+\beta_{9} O D A_{i t} \\
& +\beta_{10} \text { Inf }_{i t}+\lambda_{t}+\varepsilon_{i t}
\end{aligned}
$$

where $\alpha_{\mathrm{i}}$ is the country fixed effect, $\mathrm{MPI}_{\mathrm{i}(\mathrm{t}-1)}$ represents the lagged dependent variable in the previous period, $\lambda_{t}$ is a set of time dummies ${ }^{10}$ and $\varepsilon_{\text {it }}$ stands for the error term.

Although using variables such as total network of paved roads, railway networks and power generating capacity referring to the quality of infrastructure which can enhance poverty reduction are important; however they were excluded from the model because of the lack of data for the countries included in the study.

${ }^{10}$ The time dummies are supposed to capture period-specific effects. 
The expected signs of the independent variables are as follow:

- A positive sign of the lagged dependant variable as poverty is affected by its historical data.

- A positive or negative sign for the initial GDP per capita depending on the effects of economic growth on the rates of inequality.

- A negative sign of aggregate governance indicators which refers to the quality of institutions that could play an important role in poverty reduction.

- A positive sign of unemployment rate as the increase of unemployment increases the gap between the potential and actual GDP and increases the dependency ratio which increases poverty.

- A negative sign of the total health expenditure as a percentage of GDP because increasing spending on health care results in reducing the pressure on the poor and also putting into consideration the multidimensional phenomenon of poverty.

- A negative sign of the government expenditure on education as a share of GDP as an indication of the investment in human capital because subsidizing education and enhancing the quality of education reduces the pressure on the poor and enhance their abilities to engage in the labor market.

- A negative sign of the improved sanitation facilities as a percentage of population with access, as the improvements in physical infrastructure enhances the standard of living and reduces the pressure on the poor.

- The sign of trade openness is ambiguous as the relationship between trade liberalization and poverty is less clear because it differs from one country to another depending on its circumstances and the characteristics of the poor. 
- An ambiguous sign for net official development assistance because of the debate regarding the effect of foreign assistance on developing countries.

- A positive or negative sign for inflation which exists in two effects. The first is that the increase of the annual growth rate of the GDP deflator leads to reducing real-wages and increases poverty. The second is that workers attempt to compensate for the decline in real income through rising employment and creating more income-earning opportunities. Additionally, most of the poor are net debtors and inflation can reduce the real value of their debt. The sign depends on which effect outweighs the other.

It is clear that improving the conditions related to institutions, physical infrastructure, unemployment and human capital help in reducing poverty, but the reverse causality cannot be ignored. As the country becomes less poor, it invests more in education, health care and physical infrastructure and experiences an improvement in the quality of institutions. Consequently, a dynamic Generalized Method of Moments (GMM) panel estimator is used to deal with the endogeneity problem ${ }^{11}$ and to avoid the biasness of results and the doubts on reliability (Agboghoroma et al., 2009; Arellano and Bond, 1991; Stephen and Mahyudin, 2014).

Arellano and Bond (1991) used the first differences in the levels of the equation in order to eliminate the individual effects in estimating the dynamic GMM model and simultaneously used the differenced endogenous and predetermined explanatory variables with their levels in previous periods as instruments. This can produce efficient and consistent estimates, and at the

${ }^{11}$ This is done by using a set of instruments for the endogenous variables. 
same time take all the potential orthogonality conditions into account. Accordingly, equation 1 can be rewritten as:

$$
\begin{aligned}
\Delta M P I_{i t}= & \beta_{1} \Delta M P I_{i(t-1)}+\beta_{2} \Delta \text { InitialGDBc } c_{i t}+\beta_{3} \Delta W G I_{i t}+\beta_{4} \Delta U n e m r_{i t} \\
& +\beta_{5} \Delta \text { Health }_{i t}+\beta_{6} \Delta E d u \exp _{i t}+\beta_{7} \Delta I S F_{i t}+\beta_{8} \Delta \text { Trade }_{i t} \\
& +\beta_{9} \Delta O D A_{i t}+\beta_{10} \Delta I n f_{i t}+\Delta \varepsilon_{i t}
\end{aligned}
$$

Agboghoroma et al. (2009) reviewed the studies that mentioned the weaknesses of using the difference GMM estimator showing that lagged levels can be poor instruments for first-differenced variables, in particular if the variables are persistent. In a modification of the estimator, system GMM estimator for dynamic panel data model is used. This model combines lagged levels to be included as instruments for the difference equation and lagged differences as instruments in the level equation. Accordingly, equations (1) and (2) are estimated simultaneously using system dynamic GMM.

\section{Data Sources}

In order to test the implications of the model, data are collected from several sources depending on the availability of the data of the selected countries. Data of multidimensional poverty index (MPI) are calculated depending on two sources. The first is the Millennium Development Goals Indicators for the deprivation of decent living standards data. The second is the World Development Indicators for the data on the deprivation of longevity. The data on initial GDP per capita, inflation, improved sanitation facilities, net official development assistance, trade as a share of GDP, health expenditure and unemployment are collected from World Development Indicators of the World Bank national accounts data. The government expenditure on education as a percentage of GDP 
data is collected from The United Nations Educational Scientific and Cultural Organization (UNESCO) Institute for Statistics. The Worldwide Governance Indicators are generated from The World Bank data.

\section{Empirical Results}

Following the description of the variables and the econometric method used, equations (1) and (2) are estimated using a system GMM estimator for dynamic panel data model. Both levels and differences in the multidimensional poverty index across countries and time are explained by multidimensional poverty index of the previous period " $\mathrm{MPI} \mathrm{I}_{\mathrm{i}(\mathrm{t}-}$ 1)", the level of initial GDP per capita "InitialGDPpc", the quality of institutions "WGI", the unemployment rate "Unemr", the health expenditure as a percentage of GDP "Health", the government expenditure on education "eduexp", the improved sanitation facilities "ISF", the degree of trade openness "Trade", net official development assistance "ODA", the inflation rate "Inf". Additionally, a dummy variable is added to evaluate the effect of the combined package of activities included in the AfT initiative "DumAfT".

There are 6 potentially endogenous independent variables (InitialGDPpc, WGI, Health, Trade, eduexp and ISF) in addition to 4 exogenous independent variables (Unemr, DumAfT, ODA and Inf).

The pooled ordinary least square (OLS) and panel fixed effect methods are employed as robustness tests. Moreover, the existence of the fixed effects is tested using redundant fixed effects - likelihood ratio. The results strongly reject that the cross-section effects are redundant. The values of ArellanoBond test of autocorrelation (AB (2)) imply that problems of second order autocorrelation in differences can be rejected. The 
values of the Sargan test show that the instruments are valid as it implies ignoring the over-identifying restrictions.

The coefficients of all the significant variables have the expected signs. Multidimensional poverty index of the previous period, unemployment, inflation and trade openness have positive influence on the multidimensional poverty index while initial GDP per capita, the quality of institutions, the health expenditure, the government expenditure on education, the improved sanitation facilities and the net official development assistance have the expected negative effects on the multidimensional poverty index.

The Multidimensional poverty index of the previous period, institutional quality and health expenditure are significant at the $1 \%$ level. The trade openness, inflation and unemployment rate variables are significant at the 5\% level. The initial level of GDP per capita, government expenditure on education, improved sanitation facilities, and net official development assistance are significant at the $10 \%$ level. The time dummy for the AfT initiative is insignificant although it has the negative sign.

In table 1 the determinants of multidimensional poverty index shown in the results of estimation are reported. In column 1 of the table, the results of the main equation are reported as well. In column 2, the results of the effect of health expenditure is shown. And in column 3, the effect of government expenditure on education is tested. In column 4 , the improved physical infrastructure is added to the model using the improved sanitation facilities as a proxy for improving physical infrastructure. In column 5, the effects of trade openness on multidimensional poverty is tested. In column 6 , net official development assistance is added to the model. In column 7, inflation is added to the model to test its effects on multidimensional poverty. Adding the variables, those are 
expected to affect multidimensional poverty, to models from 2 to 7 don't fundamentally change the significance level, nor the direction of the effect of the first main regression.

\begin{tabular}{|c|c|c|c|c|c|c|c|}
\hline \multirow{2}{*}{$\begin{array}{c}\text { Independent } \\
\text { Variables }\end{array}$} & \multicolumn{7}{|c|}{ Dependant Variable: $\ln \mathrm{MPI}_{\mathrm{it}}$} \\
\hline & 1 & 2 & 3 & 4 & 5 & 6 & 7 \\
\hline $\ln \mathrm{MPI}_{\mathrm{i}(\mathrm{t}-1)}$ & $\begin{array}{c}0.9948^{* *} \\
* \\
(203.88)\end{array}$ & $\begin{array}{l}1.0031^{* *} \\
{ }^{*} \\
(248.58)\end{array}$ & $\begin{array}{c}0.9959^{* *} \\
* \\
(239.16)\end{array}$ & $\begin{array}{c}0.9872^{* *} \\
\text { (127.84) }\end{array}$ & $\begin{array}{l}1.0028^{* *} \\
* \\
(199.45)\end{array}$ & $\begin{array}{c}1.001^{* *} \\
* \\
(187.88 \\
)\end{array}$ & $\begin{array}{l}0.999^{* * *} \\
(312.25)\end{array}$ \\
\hline $\begin{array}{l}\text { ln } \\
\text { InitialGDPp } \\
\text { c }\end{array}$ & $\begin{array}{l}-0.001^{*} \\
(-1.807)\end{array}$ & $\begin{array}{l}-0.0002^{*} \\
(-1.649)\end{array}$ & $\begin{array}{l}-0.0002^{*} \\
(-1.738)\end{array}$ & $\begin{array}{l}-0.0002^{*} \\
(-1.676)\end{array}$ & $\begin{array}{l}-0.0002^{*} \\
(-1.785)\end{array}$ & $\begin{array}{c}- \\
0.0002^{*} \\
(- \\
1.814)\end{array}$ & $\begin{array}{l}-0.0002^{*} \\
(-1.781)\end{array}$ \\
\hline $\ln$ WGI & $\begin{array}{c}- \\
2.851^{* * *} \\
(-2.949) \\
\end{array}$ & $\begin{array}{c}- \\
3.175^{* * *} \\
(-3.112)\end{array}$ & $\begin{array}{c}- \\
3.165^{* * *} \\
(-3.111)\end{array}$ & $\begin{array}{c}- \\
2.843^{* * *} \\
(-3.030)\end{array}$ & $\begin{array}{l}-3.346^{* * *} \\
(-3.213)\end{array}$ & $\begin{array}{c}- \\
3.292^{* *} \\
* \\
(- \\
3.148)\end{array}$ & $\begin{array}{c}-3.066^{* * *} \\
(-3.139)\end{array}$ \\
\hline ln Unemr & $\begin{array}{c}0.0005^{* *} \\
(1.886)\end{array}$ & 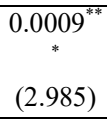 & $\begin{array}{c}0.0006^{* *} \\
(2.537)\end{array}$ & $\begin{array}{c}0.0009^{* *} \\
* \\
(3.061)\end{array}$ & $\begin{array}{c}0.0005^{* *} \\
(1.696)\end{array}$ & $\begin{array}{c}\underset{*}{0.0006^{*}} \\
(2.059) \\
\end{array}$ & $\begin{array}{c}0.0005^{* * *} \\
(3.966)\end{array}$ \\
\hline DumAfT & $\begin{array}{c}-0.005 \\
(- \\
1.1981) \\
\end{array}$ & $\begin{array}{l}-0.002 \\
(-1.644)\end{array}$ & $\begin{array}{l}-0.001 \\
(-0.207)\end{array}$ & $\begin{array}{c}-0.003 \\
(-0.772)\end{array}$ & $\begin{array}{c}-0.006 \\
(-1.623)\end{array}$ & $\begin{array}{c}-0.008 \\
(- \\
1.208) \\
\end{array}$ & $\begin{array}{l}-0.0005 \\
(-0.180)\end{array}$ \\
\hline In health & & $\begin{array}{l}- \\
0.011^{* * *} \\
(-4.299) \\
\end{array}$ & & & & & \\
\hline ln Eduexp & & & $\begin{array}{l}-0.007^{*} \\
(-1.721)\end{array}$ & & & & \\
\hline $\ln$ ISF & & & & $\begin{array}{l}-0.007^{*} \\
(-1.679) \\
\end{array}$ & & & \\
\hline ln Trade & & & & & $\begin{array}{l}0.008^{* *} \\
(2.342)\end{array}$ & & \\
\hline ODA & & & & & & $\begin{array}{c}- \\
0.0001^{*} \\
(- \\
1.760)\end{array}$ & \\
\hline$\overline{\operatorname{Inf}}$ & & & & & & & $\begin{array}{c}0.000255^{*} \\
* \\
(2.085904\end{array}$ \\
\hline
\end{tabular}


Effective Complementary Policies

Dr.Ahmed M. Ezzat

$3 / 4 / 2017$

\begin{tabular}{|l|c|c|c|c|c|c|c|}
\hline & & & & & & & ( \\
\hline \hline $\begin{array}{l}\text { Observation } \\
\text { s }\end{array}$ & 594 & 595 & 595 & 595 & 595 & 595 & 595 \\
\hline $\begin{array}{l}\text { No. of } \\
\text { countries }\end{array}$ & 48 & 48 & 48 & 48 & 48 & 48 & 48 \\
\hline $\begin{array}{l}\text { No. of } \\
\text { instruments }\end{array}$ & 35 & 36 & 28 & 27 & 30 & 30 & 39 \\
\hline $\begin{array}{l}\text { Sargan Test } \\
\text { (p-value) }\end{array}$ & 0.38 & 0.52 & 0.43 & 0.51 & 0.49 & 0.44 & 0.37 \\
\hline $\begin{array}{l}\text { AB 2 Test } \\
\text { (p-value) }\end{array}$ & 0.88 & 0.72 & 0.23 & 0.22 & 0.67 & 0.80 & 0.12 \\
\hline $\begin{array}{l}\text { Red. FE } \\
\text { Test (Chi- } \\
\text { square) }\end{array}$ & 255 & 254.61 & 307.64 & 260.89 & 253.8 & 254.79 & 254.78 \\
\hline
\end{tabular}

Significance at the 10,5 , and 1 percent level is denoted by $* * *$, and $* * *$, respectively.

Constant terms are always included but not reported.

1Sargan test of over-identifying restrictions

2 Arellano-Bond-test of second-order autocorrelation in residuals; first-order autocorrelation

is not reported.

3 Redundant Fixed Effects likelihood Ratio of testing fixed effects.

Table 1 Determinants of multidimensional poverty index.

The main findings of the model are the strongly significant effects of the historical data about multidimensional poverty in the previous periods. This confirms the vicious cycle of the poverty principle. The model magnifies the importance of initial GDP per capita in affecting multidimensional poverty and not only is economic growth required to reduce poverty, but also the redistribution of income is critical in reducing poverty. The quality of institutions is very important in reducing multidimensional poverty, especially control of corruption, government effectiveness, political stability and absence of violence, regulatory quality and rule of law. Unemployment is one of the main causes of multidimensional poverty. Enhancing human capacity building and the quality of infrastructure are essential in reducing multidimensional poverty.

Trade openness harms the interests of the poor. The negative effect of trade openness on multidimensional poverty supports 
the fact that most of the countries included in the study benefit little from the international trading system. This emphasizes the need to support efforts that aim to achieve development through trade openness on the removal of the negative effects of trade openness on poor.

\section{Discussion of the results and policy implications}

The results of this paper confirmed both the economic theory and the previous studies as all the variables included in the 7 models have the expected significant effects. The results report that the effect of trade openness on multidimensional poverty is positive and significant at 10 percent, showing that trade openness activities increases multidimensional poverty in African countries. This highlights the importance of having policies to reduce poverty coincides with the opening up trade to alleviate multidimensional poverty in Africa. In setting these policies, policy makers need to take into account the fact that breaking the vicious cycle of poverty needs to double efforts.

But the surprising result is that the AfT's dummy turned out to be insignificant in all the models although having the negative effect referred to that the components of the Aft programs failed to affect multidimensional poverty since it started on December 2005.

The efficiency of the AfT programs in reducing multidimensional poverty needs coordinating between donors and between donors and recipients to help maximize the benefits of African countries from the integration in world trade. The coordination needed includes integrating some activities with AfT programs in African countries. 
From the recipients' perspective, effective government intervention is required to enhance institutional quality through encouraging the control of corruption, government effectiveness, political stability and absence of violence, regulatory quality and rule of law. Additionally, government intervention should work on redistributing incomes to reduce poverty through mitigating the negative effects of trade liberalization on multidimensional poverty. Governments are required to enhance macroeconomic stability and eliminate any inflationary consequences resulted from the integration into global markets. Furthermore, enhancing human capacity building through focusing on the quality of health care and educational service is needed. Moreover, relying on labor intensive technologies is desired to reduce unemployment in addition to investing in the quality of physical infrastructure which is so poor in the majority of African countries and at the same time can absorb a large part of the labor force. Also, focusing more on liberalizing South- South trade can help learning-by-doing and overcome the structural adjustment costs in the short term.

From the donors' side, donors are required to align their development assistance with local development strategies in recipient countries. Aids should be focused on sectors where the recipient country has a comparative advantage in and using labor intensive technologies. Focusing parts of programs activities to enhance institutional quality, target enhancing macroeconomic stability, enhance human capacity building and support the quality of physical infrastructure. 


\section{References}

Addae-Korankye, A (2014), "Causes of Poverty in Africa: A Review of Literature," American Journal of Social Sciences, vol. 3(7): 147-153.

Agboghoroma A., M. Busse, S. Falatik, R. Hoekstra, J. Königer, G. Koopman, C. Kühne and N. Roloff (2009), Aid for Trade: making trade effective for development: Case Studies for Kenya, Tanzania and Uganda, Edited by PricewaterhouseCoopers and Hamburg Institute of International Economics (HWWI). Available at: $<$ http://www.hwwi.org/fileadmin/hwwi/Leistungen/Gutachten/Aid_f or_Trade.pdf $>$

Amiti M. and Davis D. R. (2012), "Trade, firms, and wages: theory and evidence," The Review of Economic Studies, vol. 79(1): 1-36.

Anyanwu, J. C. and A. E. O. Erhijakpor (2010), "Do International Remittances Affect Poverty in Africa?," African Development Review, vol. 22 (1): 51-91.

Arellano, M. and S. Bond (1991), "Some Tests of Specification for Panel Data: Monte Carlo Evidence and an Application to Employment Equations," Review of Economics Studies, vol. 58 (2): 277-297.

Basnett, Y., Engel, J., Kennan, J., Kingombe, C., Massa, I., te Velde, D.W. (2012), "Increasing the effectiveness of Aid for Trade: the circumstances under which it works best," ODI Working Paper No. 353, Overseas Development Institute (ODI), London. $<$ http://www19.iadb.org/intal/intalcdi/PE/2012/10688.pdf $>$

Bradshaw, T.K. (2005), "Theories of poverty and anti-poverty programs in community development," Rural Poverty Research Center Working Paper, No. 06-05: 2-22.

Egye A. U. and H. Muhammad (2015), "Analysis of Poverty Reduction Strategies as Mechanism for Development in Nigeria from 19992014," International Journal of Social, Behavioral, Educational, Economic, Business and Industrial Engineering Vol:9, No:11, $<$ http://waset.org/publications/10003056/analysis-of-povertyreduction-strategies-as-mechanism-for-development-in-nigeria-from1999-2014> 
Fosu, A.K. and A. Mold (2008), "Gains from Trade: Implications for Labour Market Adjustment and Poverty Reduction inAfrica," African Development Review, vol. 20 (1): 20-48.

Gourdon, J., N. Maystre and J. de Melo (2008), "Openness, Inequality and Poverty: Endowments Matter,", Journal of International Trade and Economic Development, 17 (3): 343-378.

Hayashikawa, M. (2009), "Trading Out of Poverty: How Aid for Trade Can Help", OECD Journal on Development, Vol. 10 (2): 7-14.

ICTSD (2012), Aid for Trade and the Least Developed Countries: Recent Trends and Impacts on the Ground: Early Findings from the Country Case Studies, Information Note, October, International Centre for Trade and Sustainable Development (ICTSD), Geneva, Switzerland.

IMF (2007), World Economic Outlook: Globalization and Inequality, International Monetary Fund, Washington, DC. $<$ https://www.imf.org/external/pubs/ft/weo/2007/02/pdf/text.pdf $>$

Jordan, G. (2004), "The Causes of Poverty - Cultural vs. Structural: Can There Be a Synthesis?" Perspectives in Public Affairs (Spring), 1: 1834.

McCaston, K. and M. Rewald (2005), "A conceptual Overview of Underlying Causes of Poverty," Atlanta, GA: CARE USA. $<$ http://pqdl.care.org/Core\%20Library/A\%20Conceptual\%20Overvie w $\% 20$ of $\% 20$ Underlying $\% 20$ Causes $\% 20$ of $\% 20$ Poverty.pdf $>$

Melo, J. and L.Wagner (2015), "Aid For Trade as finance for the Poor," FEDRI, Clermond-Ferrand.

$<$ http://www.ferdi.fr/sites/www.ferdi.fr/files/publication/fichiers/ wp 125 demelo_wagner.pdf $>$

Nicita, A., M. Olarreaga and G. Porto (2011), "Pro-Poor Trade Policy in Sub-Saharan Africa," Journal of International Economics, vol. 92 (2): 252-65.

OECD (2006), "Aid for Trade. Making It Effective", Development Dimention Series, OECD, Paris. $<$ https://www.oecd.org/trade/aft/37198197.pdf $>$

OECD (2011), "Increasing the Benefits of Trade for the Poor," in OECD, Trade for Growth and Poverty Reduction: How Aid for Trade Can Help, OECD Publishing, Paris.

$<$ http://dx.doi.org/10.1787/9789264098978-6-en> 
OECD and WTO (2007), Aid-for-Trade at a Glance 2007: $1^{\text {st }}$ Global

Review. Paris and Geneva: OECD/WTO.

$<\quad$ https://www.wto.org/english/tratop_e/devel_e/a4t_e/a4t_at_a glance07_e.pdf $>$

OECD and WTO (2011) Aid-for-Trade at a Glance 2011: Showing Results. Paris and Geneva: OECD/WTO. $<$ https://www.wto.org/english/res_e/publications_e/aid4trade11_e.pd $\mathrm{f}>$

OECD and WTO (2013), "Evaluating the effectiveness of aid for trade", in Aid for Trade at a Glance 2013: Connecting to Value Chains, WTO, Geneva/OECD Publishing, Paris. $<$ http://dx.doi.org/10.1787/aid glance-2013-9-en>

OECD and WTO (2015), Aid-for-Trade at a Glance 2015: Reducing Trade Costs for Inclusive, Sustainable Growth. Paris and Geneva: OECD/WTO.

$<$ https://www.wto.org/english/res_e/booksp_e/aid4trade15_e.pdf $>$

Pinstrup-Andersen, P. (1998), "Changing approaches to development aid: the effect on international stability," Global Governance, vol.4: 381394.

Stark, B. (2009), "Theories of Poverty/The Poverty of Theory," BYU Law Review, vol. 2009 (2): 381-430.

Stephen G. H. and Mahyudin A. (2014), "Revisiting the institutionsgrowth nexus in developing countries: The new evidence," New Zealand Economic Papers, Taylor \& Francis Journals, vol. 48(3): 301-312.

Turner, L., N. Nguyen and K. Bird (2008), An overview of Ex Ante Tools for Assessing the Impact of Trade Libralisation on the Poor, report prepared for BMZ/GTZ (German Federal Ministry for Economic Cooperation and Development), Overseas Development Institute, London.

$<$ https://www.giz.de/expertise/downloads/giz2008-en-impact-tradeliberalisation-on-the-poor-study.pdf $>$

UNCTAD, (2012), "Aid for trade: A failing grade in LDCs?," Policy Brief No 2, April. Geneva. $<$ http://unctad.org/en/PublicationsLibrary/uxiiipb2012d2_en.pdf $>$

Versailles, B. (2012), "Rwanda: budgeting and planning processes," Overseas Development Institute (ODI ) Budget Strengthening 
Initiative, Country Learning Notes, April, Overseas Development Institute.

$<$ http://static1.1.sqspcdn.com/static/f/1349767/18085923/133647537

8620/rwanda-budgeting-and-planning.pdf.html>

Winters, A. and A. Martuscelli, (2014), "Trade Liberalization and Poverty: What Have we Learned in a Decade", Annual Review of Resource Economics, vol. 6 (1): 493-512. 


\section{Appendix}

Country Sample

\begin{tabular}{|l|l|l|l|}
\hline \multicolumn{2}{|l|}{ Developing Countries } & \multicolumn{2}{l|}{ Least Developed Countries } \\
\hline 1 & Algeria & 1 & Angola \\
\hline 2 & Botswana & 2 & Benin \\
\hline 3 & Cameroon & 3 & Burkina Faso \\
\hline 4 & Congo, Rep. & 4 & Burundi \\
\hline 5 & Cote d'Ivoire & 5 & Central African Republic \\
\hline 6 & Egypt, Arab Rep. & 6 & Chad \\
\hline 7 & Gabon & 7 & Comoros \\
\hline 8 & Ghana & 8 & Congo, Dem. Rep. \\
\hline 9 & Kenya & 9 & Djibouti \\
\hline 10 & Mauritius & 10 & Equatorial Guinea \\
\hline 11 & Morocco & 11 & Ethiopia \\
\hline 12 & Namibia & 12 & Gambia \\
\hline 13 & Nigeria & 13 & Guinea \\
\hline 14 & Seychelles & 14 & Guinea-Bissau \\
\hline 15 & South Africa & 15 & Lesotho \\
\hline 16 & Swaziland & 16 & Liberia \\
\hline 17 & United Republic of Tanzania & 17 & Madagascar \\
\hline 18 & Tunisia & 18 & Malawi \\
\hline 19 & Zambia & 19 & Mali \\
\hline 20 & Zimbabwe & 20 & Mauritania \\
\hline & & 21 & Mozambique \\
\hline & & 22 & Niger \\
\hline & & 23 & Rwanda \\
\hline & & 24 & Senegal \\
\hline & & 25 & Sierra Leone \\
\hline & & 26 & Sudan \\
\hline & & 27 & Togo \\
\hline & & 28 & Uganda \\
\hline
\end{tabular}

The classification followed the United Nations - The World Economic Situation and Prospects (WESP). 
